\title{
IncP-mediated transfer of loci involved with gas vesicle production in Ancylobacter aquaticus
}

\author{
C. Bittle and Allan Konopka* \\ Department of Biological Sciences, Purdue University, West Lafayette, IN 47907, USA
}

(Received 7 November 1989; revised 19 February 1990; accepted 26 March 1990)

\begin{abstract}
IncP plasmids were transferred by conjugation from Escherichia coli to gas-vacuolate strains of Ancylobacter aquaticus, between strains of $A$. aquaticus, and from $A$. aquaticus to $E$. coli. These plasmids would also mobilize the chromosome of $A$. aquaticus. In this way, $A$. aquaticus genes could complement mutations in either $A$. aquaticus or $E$. coli. A locus involved in gas vesicle production was co-transferred with rifampicin resistance in matings between strains of $A$. aquaticus.
\end{abstract}

\section{Introduction}

Ancylobacter aquaticus (Raj, 1983), formerly Microcyclus aquaticus, is a Gram-negative heterotrophic bacterium that has been isolated from aquatic habitats. Some strains contain intracellular inclusions called gas vesicles (Konopka et al., 1976; Van Ert \& Staley, 1971), and these hollow proteinaceous structures can provide buoyancy if they occur in sufficient quantity (Walsby, 1971, 1978).

Gas vesicles occur in phylogenetically diverse species of bacteria, including many cyanobacteria (Walsby, $1981 a$ ), heterotrophic eubacteria (Walsby, 1981 b), and archaeobacteria such as Halobacterium (Horne et al., 1988) and methanogens (Zinder et al., 1987). Genes encoding gas vesicle proteins have been cloned from Calothrix sp. PCC 7601 (Tandeau de Marsac et al., 1985), Anabaena flos-aquae (Hayes et al., 1988) and Halobacterium halobium (Horne et al., 1988). These genes have been detected in a wide variety of cyanobacteria (Damerval $e t$ al., 1989) and several isolates of halobacteria (Horne et al., 1988).

Neither the cyanobacteria nor halobacteria from which gas vesicle genes have been cloned are amenable to genetic analysis. Escherichia coli clones containing gas vesicle genes have not been reported to produce gas vesicle protein. Ancylobacter aquaticus is a unicellular bacterium that grows on chemically defined media, and it may provide a useful system in which to conduct molecular and genetic analyses of gas vesicle assembly. In this report, we provide evidence that broad-host-range IncP plasmids (Thomas \& Smith, 1987) can be used to transfer DNA (including chromosomal markers) between $A$. aquaticus strains and between $E$. coli and $A$. aquaticus. Furthermore, we were able to complement non-gas-vacuolate $A$. aquaticus mutants with this system.

\section{Methods}

Bacterial strains and plasmids. Strains of A. aquaticus and E. coli, and IncP plasmids used in this study, are described in Table 1. Derivatives of $A$. aquaticus $\mathrm{Ml}$ typically have a non-motile phenotype, but phase variants which are motile (such as strain M7) can be selected (Lara \& Konopka, 1987).

Media and growth conditions. A. aquaticus was grown in either CAGV or DM medium. CAGV contained $\left(1^{-1}\right) ; 1 \mathrm{~g}$ glucose, $1 \mathrm{~g}$ Casamino acids, $20 \mathrm{ml}$ Hutner's salts and $5 \mathrm{ml}$ vitamin solution (Staley, 1968). DM contained $\left(1^{-1}\right): 20 \mathrm{ml}$ Hutner's salts, $5 \mathrm{ml}$ vitamin solution, $1 \mathrm{~g}$

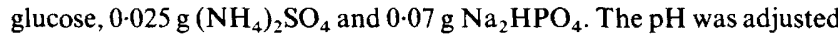
to 7.2 prior to autoclaving. E. coli strains were grown in L-broth (Miller, 1972) or Difco nutrient broth.

Antibiotics were added to media to the following concentrations: streptomycin (Str), $100 \mu \mathrm{g} \mathrm{ml}-1$, kanamycin $(\mathrm{Km}), 100 \mu \mathrm{g} \mathrm{ml}-1$, rifampicin (Rif), $30 \mu \mathrm{g} \mathrm{ml}^{-1}$, ampicillin (Ap), $25 \mu \mathrm{g} \mathrm{ml}^{-1}$, tetracycline (Tc) $20 \mu \mathrm{g} \mathrm{ml}^{-1}$.

$A$. aquaticus strains were grown at $30^{\circ} \mathrm{C}$, and $E$. coli strains were grown at $37^{\circ} \mathrm{C}$. Broth cultures were incubated in a New Brunswick controlled-environment incubator-shaker.

Mating procedures. Matings were incubated at $30^{\circ} \mathrm{C}$ for $24 \mathrm{~h}$, unless otherwise indicated. For chromosome transfer between $A$. aquaticus strains, matings were left for $48 \mathrm{~h}$. The data presented on mating experiments are the results from a typical experiment.

Non-quantitative patch matings were performed by picking individual colonies of donor and recipient with sterile toothpicks. These were mixed together on agar plates. L-agar or nutrient agar was used as the medium for matings which involved $E$. coli. CAGV agar was used when $A$. aquaticus strains were the donor and recipient.

For quantitative matings, cultures of the donor and recipient were grown in the appropriate liquid medium to densities of $10^{8} \mathrm{ml}^{-1}$. Cells were harvested by centrifugation and resuspended in medium to densities of $10^{9} \mathrm{ml}^{-1}$. A $0 \cdot 1 \mathrm{ml}$ sample of recipient was spotted onto a 
Table 1. Bacterial strains and plasmids

\begin{tabular}{|c|c|c|}
\hline Designation & $\begin{array}{l}\text { Relevant markers } \\
\text { and properties* }\end{array}$ & Comments and source \\
\hline \multicolumn{3}{|l|}{ A. aquaticus } \\
\hline M1 & Wild-type Ves ${ }^{+}$ & Van Ert \& Staley (1971) \\
\hline M7 & Ves $^{-}$Mot $^{+}$ & Lara \& Konopka (1987) \\
\hline M16 & $\mathrm{Ves}^{-}$ & Spontaneous mutant of M1, this study \\
\hline M100 & $\mathrm{Ves}^{\mathrm{C}}$ & Konopka et al. (1976); formerly strain S1 \\
\hline M123 & Ves $^{-}$Str $^{R}$ & Derived from M16, this study \\
\hline M125 & $\mathrm{Ves}^{+} \mathrm{Str}^{\mathrm{R}}$ & Derived from $\mathrm{M} 1$, this study \\
\hline M127 & Ves $^{+}$Rif $^{\text {R }}$ & Derived from $\mathrm{M} 1$, this study \\
\hline M130 & $\operatorname{Ves}^{\mathrm{C}} \mathrm{Rif}^{\mathrm{R}}$ & Derived from $\mathrm{M} 100$, this study \\
\hline M136 & Ves $^{-}$Str $^{R}$ & $\begin{array}{l}\text { Derived from } \mathrm{M} 22 \text {, a UV-induced } \mathrm{Ves}^{-} \\
\text {mutant of } \mathrm{M} 1 \text {, this study }\end{array}$ \\
\hline M201 & Ves $^{-}$Rif $^{R}$ & Derived from $M 16$, this study \\
\hline \multicolumn{3}{|l|}{ E. coli } \\
\hline CU981 & thr leu thi & Obtained from H. E. Umbarger \\
\hline HB5 & hag & Obtained from P. Greenberg \\
\hline HB101 & $\begin{array}{l}\text { recA hsdM hsdR pro } \\
\text { leu gal ara }\end{array}$ & Obtained from A. Aronson \\
\hline \multicolumn{3}{|l|}{ Plasmids } \\
\hline RP4 & $\mathrm{Km}^{\mathrm{R}} \mathrm{Ap}^{\mathrm{R}} \mathrm{Tc}^{\mathrm{R}}$ & Obtained from H. E. Umbarger \\
\hline RP68.45 & $\mathrm{Km}^{\mathrm{R}} \mathrm{Ap}^{\mathrm{R}} \mathrm{Tc}^{\mathrm{R}} \mathrm{Cma}^{+}$ & Obtained from B. L. Marrs \\
\hline pBLM2 & $\mathrm{Km}^{\mathrm{R}} \mathrm{Ap}^{\mathrm{R}} \mathrm{Cma}^{+}$ & Marrs (1981) \\
\hline
\end{tabular}

* Abbreviations: $\mathrm{Ves}^{+}$, produces gas vesicles; $\mathrm{Ves}^{-}$, produces no gas vesicles; $\mathrm{Ves}^{\mathrm{C}}$, constitutive gas vesicle production; $\mathbf{M o t}^{+}$, motile; $\operatorname{Str}^{\mathbf{R}}$, streptomycin resistant; $\mathbf{R i f}^{\mathrm{R}}$, rifampicin resistant; $\mathrm{Km}^{\mathrm{R}}$, kanamycin resistant; $\mathrm{Ap}^{\mathrm{R}}$, ampicillin resistant; $\mathrm{Tc}^{\mathrm{R}}$, tetracycline resistant; $\mathrm{Cma}^{+}$, enhanced chromosome-mobilization ability.

plate and allowed to dry for $0 \cdot 25-1 \mathrm{~h}$. Then $0 \cdot 1 \mathrm{ml}$ of donor suspension was spotted over the recipient. The mating mix was incubated at $25^{\circ} \mathrm{C}$ for $1-4 \mathrm{~h}$, and then incubated at $30^{\circ} \mathrm{C}$. After the incubation period, the mating mix was scraped from the plate with an inoculating loop and resuspended in $3 \mathrm{ml}$ of medium. Dilutions were made, and samples were spread onto selective solid media for enumeration. The frequency of transfer was calculated as the number of exconjugants per donor cell present at the beginning of the mating.

Matings on filters involved collection of $1 \times 10^{9}$ cells of both donor and recipient on a $0.45 \mu \mathrm{m}$ pore size Gelman Metricel filter. The filter was placed on an L-agar plate and incubated for $24 \mathrm{~h}$. Cells were removed from the filter by placing it in $5 \mathrm{ml}$ sterile $\mathrm{DM}$ media and agitating on a vortex mixer for 3-5 min.

Antibody reactions. Antibody to A. aquaticus flagellar protein was provided by Dr J. C. Lara (Lara \& Konopka, 1987). A $10 \mu \mathrm{l}$ sample of each motile variant or recombinant to be tested was placed in each of two $1.5 \mathrm{ml}$ Eppendorf tubes. One microlitre of antibody was added to one tube, and the samples were mixed and incubated for 30-60 min at $25^{\circ} \mathrm{C}$ before examination by phase-contrast microscopy for loss of motility and clumping. The extent of immotility was compared to a positive control (motile $A$. aquaticus M7) and to the sample of motile culture that did not receive antibody.

\section{Results}

Matings between $E$. coli containing the IncP plasmids RP4, R68.45 or pBLM2 and A. aquaticus M1 all resulted in the isolation of $\mathrm{Km}^{\mathrm{R}}$ clones of strain M1. The frequency of transfer for the three plasmids ranged from $10^{-2}$ to $10^{-3}$ (Table 2).
Several criteria were examined in matings between $E$. coli CU981 and A. aquaticus M1 to determine the optimal conditions for RP4 transfer between these species. The highest frequency of transfer occurred after $24 \mathrm{~h}$; longer periods of mating decreased the number of $\mathrm{Km}^{\mathrm{R}}$ exconjugants (Fig. 1). The frequency of plasmid transfer was $10^{-2}-10^{-3}$ per donor cell when quantitative matings (see Methods) were performed on L-agar or nutrient agar, $10^{-6}$ on CAGV agar, and transfer was not observed when the strains were mated on DM + glucose. Matings placed directly on agar plates resulted in plasmid transfer frequencies of about $10^{-2}$, whereas a transfer frequency of $10^{-4}-10^{-5}$ was found when cells were concentrated on filters which were then placed on agar media. Donor :recipient ratios ranging from $3: 1$ to $1: 10$ yielded similar plasmid transfer frequencies, which ranged from $10^{-1}$ to $10^{-3}$ in individual experiments. However, ratios greater than $3: 1$ resulted in transfer frequencies of less than $5 \times$ $10^{-5}$.

Transfer of IncP plasmids between strains of $A$. aquaticus was attempted by mating at $30^{\circ} \mathrm{C}$ for $24 \mathrm{~h}$. Transfer of RP4, R68.45 and pBLM2 from a $\mathrm{Str}^{\mathrm{s}}$ to a $\mathrm{Str}^{R}$ strain was confirmed by isolation of $\mathrm{Str}^{R} \mathrm{Km}^{\mathrm{R}}$ exconjugants at a frequency of approximately $10^{-2}$ for each of the three plasmids. The frequency of RP4 transfer was the same when matings were performed on L-agar or CAGV agar. 
Table 2. Inter- and intra-generic transfer of IncP plasmids

\begin{tabular}{llll}
\hline \hline Donor & Plasmid & Recipient & $\begin{array}{c}\text { Transfer frequency* } \\
\text { of } \mathrm{Km}^{\mathrm{R}}\end{array}$ \\
\hline E. coli & & A. aquaticus \\
CU981 & RP4 & M1 & $2 \times 10^{-2}$ \\
HB101 & R68.45 & M1 & $2 \times 10^{-3}$ \\
HB101 & pBLM2 & M1 & $2 \times 10^{-3}$ \\
A. aquaticus & & A. aquaticus & \\
M1 & RP4 & M123 & $1 \times 10^{-2}$ \\
M1 & R68.45 & M123 & $1 \times 10^{-2}$ \\
A. aquaticus & & E. coli & \\
M130 & RP4 & HB101 & $10^{-2}-10^{-4}$ \\
M130 & R68.45 & HB101 & $10^{-2}-10^{-4}$ \\
\hline \hline
\end{tabular}

* Transfer frequencies are expressed per donor cell. In matings between $E$. coli strains and $A$. aquaticus M1, exconjugants were selected on glucose minimal medium (DM) with $\mathrm{Km}$. Matings between $A$. aquaticus strains in which M123 was the recipient used CAGV medium plus Str and $\mathrm{Km}$ to select exconjugants. $E$. coli exconjugants that arose from matings with $A$. aquaticus were detected on $\mathrm{L}$-agar plus $\mathrm{Km}$ after $24 \mathrm{~h}$. Slow-growing $A$. aquaticus required $3 \mathrm{~d}$ to form colonies on $\mathrm{L}$ agar.

Patch matings were performed to determine whether these three plasmids could mobilize the chromosomal genes for Str or Rif resistance between strains of $A$. aquaticus (Table 3). Transfer of chromosomal markers for Str or Rif resistance did not occur unless matings were incubated for $36-48 \mathrm{~h}$.

Selection for chromosomal transfer was made by plating onto CAGV agar containing either Str and Rif or $\mathrm{Km}+\mathrm{Str}+\mathrm{Rif}$. All exconjugants selected on Str + Rif plates appeared to also contain the plasmid, because they were also $\mathrm{Km}^{\mathrm{R}}$. Quantitative matings indicated that the frequency of Rif ${ }^{\mathrm{R}}$ transfer mediated by RP4 was $3 \times$ $10^{-6}$. The rate of spontaneous mutation to $\mathrm{Rif}^{\mathrm{R}}$ in these strains was 300 -fold lower $\left(10^{-8}\right)$. Mobilization of $\mathrm{Rif}^{\mathrm{R}}$ by $\mathrm{R} 68.45$ occurred at a frequency fourfold lower than with RP4. When pBLM2 was used as the mobilizing plasmid, the frequency of $\mathrm{Rif}^{\mathrm{R}}$ recipients was similar to the rate of spontaneous mutation to $\mathrm{Rif}^{\mathrm{R}}$. When the complementary matings were performed (transfer of $\operatorname{Str}^{R}$ from a donor to a $\mathrm{Rif}^{\mathrm{R}}$ recipient), only $\mathrm{R} 68.45$ and pBLM2 transferred $\operatorname{Str}^{\mathbf{R}}$ at a frequency significantly greater than the rate of spontaneous Str resistance $\left(10^{-9}\right)$.

In the experiments testing chromosome mobilization, the donor strains were $\mathrm{Ves}^{+}$, whereas the recipients were non-gas-vacuolate mutants. Co-transfer of the $\mathrm{Ves}^{+}$ phenotype with $\mathrm{Rif}^{\mathrm{R}}$ occurred at frequencies up to $50 \%$ in exconjugants of $A$. aquaticus M123 or M136. The frequency of co-transfer varied in individual experiments from 5 to $50 \%$. No co-transfer of the $\mathrm{Ves}^{+}$ phenotype was observed when transfer of $\mathrm{Str}^{\mathrm{R}}$ to a Ves ${ }^{-}$ recipient was selected.

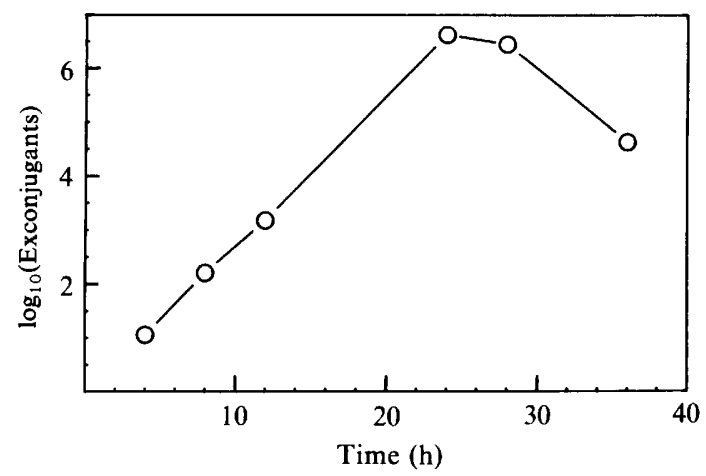

Fig. 1. Frequency of plasmid RP4 transfer between E. coli CU981 and A. aquaticus $\mathrm{Ml}$ as a function of the duration of mating. The transfer frequency is expressed as the number of $\mathrm{Km}^{\mathrm{R}}$ exconjugants per $10^{8}$ donor cells.

A. aquaticus M130 has a phenotype in which gas vesicle production is constitutive. In the wild-type, strain M1, the addition of L-lysine inhibits gas vesicle production. Linkage of the putative regulatory gene to the locus that converted strain M123 to the $\mathrm{Ves}^{+}$ phenotype was tested by mating M130(RP4) to M123. Transfer of Rif ${ }^{\mathrm{R}}$ was selected on CAGV medium, which permits expression of the $\mathrm{Ves}^{+}$phenotype. $\mathrm{Ves}^{+}$exconjugants were tested for the ability to produce gas vesicles in media containing L-lysine. Ninety percent of them failed to produce gas vesicles under these conditions. Thus, there was not strong linkage between these two loci involved in gas vesicle production.

Six other $\mathrm{Ves}^{-}$derivatives of $A$. aquaticus $\mathrm{M} 1$ were mated to strain M130(RP4), and Rif ${ }^{\mathrm{R}}$ exconjugants were selected. We observed co-transfer of the $\mathrm{Ves}^{+}$phenotype in only one of these strains.

Experiments were also performed to determine whether the IncP plasmids could be used to mobilize chromosomal markers of $A$. aquaticus that would complement mutations in E. coli. E. coli $\mathrm{HB} 101$ was chosen as the recipient, because it contains several mutations that might be complemented and it is defective in recombination and restriction. When $A$. aquaticus $\mathrm{M} 130$ (RP4) was the donor, $E$. coli exconjugants were isolated in which the pro, gal or ara lesions had been complemented. With M130(R68.45), complementation of the pro, gal or leu loci was observed. The frequency of gal complementation in these experiments was measured to be $3 \times 10^{-6}$ or $7 \times 10^{-6} \mathrm{Gal}^{+}$exconjugants per donor cell for M130(RP4) or M130(R68.45), respectively. The frequency of reversion to $\mathrm{Gal}^{+}$by $\mathrm{HB} 101$ was $<10^{-9}$.

We were also able to complement a defective flagellin gene in $E$. coli $\mathrm{HB} 5$ by mating with $A$. aquaticus. Gasvacuolate strains of $A$. aquaticus are non-motile; however, flagellated non-gas-vacuolate variants can be 
Table 3. Mobilization of chromosomal antibiotic resistance markers in A. aquaticus by IncP plasmids

\begin{tabular}{|c|c|c|c|c|c|}
\hline \multicolumn{2}{|r|}{ Donor } & \multicolumn{2}{|c|}{ Recipient } & \multirow{2}{*}{$\begin{array}{l}\mathrm{Rif}^{\mathrm{R}} \text { or } \mathrm{Str}^{\mathrm{R}} \\
\text { exconjugants per donor* }\end{array}$} & \multirow{2}{*}{$\begin{array}{c}\text { Percentage } \\
\text { Ves }^{+}\end{array}$} \\
\hline Strain & Phenotype & Strain & Phenotype & & \\
\hline M127 & $\mathrm{Rif}^{\mathrm{R}} \mathrm{Ves}^{+}(\mathrm{RP} 4)$ & M136 & $\mathrm{Str}^{\mathrm{R}} \mathrm{Ves}^{-}$ & $3 \times 10^{-6}$ & 50 \\
\hline M127 & Rif $^{\mathrm{R}}$ Ves $^{+}$(RP68.45) & M123 & Str $^{\mathrm{R}} \mathrm{Ves}^{-}$ & ND & 50 \\
\hline M127 & $\mathrm{Rif}^{\mathrm{R}} \mathrm{Ves}^{+}$(RP68.45) & M136 & $\mathrm{Str}^{\mathrm{R}} \mathrm{Ves}^{-}$ & $8 \times 10^{-7}$ & 10 \\
\hline M127 & $\mathrm{Rif}^{\mathrm{R}} \mathrm{Ves}^{+}(\mathrm{pBLM} 2)$ & M123 & Str $^{R}$ Ves $^{-}$ & ND & 20 \\
\hline M127 & Rif $^{\mathrm{R}} \mathrm{Ves}^{+}(\mathrm{pBLM} 2)$ & M136 & $\mathrm{Str}^{\mathrm{R}} \mathrm{Ves}^{-}$ & $2 \times 10^{-8}$ & 5 \\
\hline M130 & Rif $^{\mathrm{R}}$ Ves $^{\mathrm{C}}$ (RP4) & M123 & StrR $^{\mathrm{R}} \mathrm{Ves}^{-}$ & $3 \times 10^{-6}$ & 25 \\
\hline M125 & Str $^{\mathrm{R}} \mathrm{Ves}^{+}(\mathrm{R} 68.45)$ & M201 & Rif $^{\mathrm{R}} \mathrm{Ves}^{-}$ & $1.4 \times 10^{-6}$ & 0 \\
\hline M125 & Str $^{\mathrm{R}} \mathrm{Ves}^{+}(\mathrm{pBLM} 2)$ & M201 & Rif $^{\mathrm{R}}$ Ves $^{-}$ & $2 \cdot 0 \times 10^{-6}$ & 0 \\
\hline M125 & Str $^{\text {R }}$ Ves $^{+}$(RP4) & M201 & $\operatorname{Rif}^{\mathrm{R}} \mathrm{Ves}^{-}$ & $1.2 \times 10^{-9}$ & 0 \\
\hline
\end{tabular}

ND, Not determined.

* Exconjugants were selected on CAGV agar containing either Str and Rif or Km, Str and Rif.

selected (Lara \& Konopka, 1987). Thus, phenotypically non-motile strains contain the genetic information for formation of flagella. A. aquaticus M100(RP4) was mated to a $\mathrm{Str}^{\mathrm{R}}$ derivative of $E$. coli $\mathrm{HB} 5$, and exconjugants were selected on nutrient agar containing Kan and Str. Two of seventy colonies that were inoculated into $0.35 \%$ agar media exhibited diffuse growth in $10 \mathrm{~d}$. Motility was confirmed when samples were examined microscopically.

Two pieces of evidence suggest that the motile derivatives of HB5 arose due to gene transfer from $A$. aquaticus. (1) No motile revertants of HB5 were isolated by repeated inoculation of $0 \cdot 35 \%$ agar plates with HB5 alone. (2) Antibody to purified $A$. aquaticus flagellin inhibited motility of the exconjugants, but had no effect upon motility of wild-type $E$. coli.

\section{Discussion}

This study was undertaken to examine the feasibility of establishing genetic exchange in gas-vacuolate $A$. aquaticus using broad-host-range plasmids. We found that several IncP plasmids could be transferred between strains of A. aquaticus or between A. aquaticus and E. coli. This result was not surprising, because successful transfer of IncP plasmids has been reported between a wide variety of Gram-negative genera (Thomas \& Smith, 1987).

The three IncP plasmids we employed were also capable of mobilizing chromosomal genes in A. aquaticus. Several $E$. coli mutations, responsible for defects in catabolic, biosynthetic or motility functions, were complemented with $A$. aquaticus DNA mobilized via IncP plasmids. Resistance to Str or Rif, which typically results from mutations in chromosomal genes (Gale et al., 1981), arose at a frequency $100-1000$ times the spontaneous mutation rate in $A$. aquaticus when the appropriate strains of $A$. aquaticus were mated employing an IncP plasmid. Plasmids R68.45 and pBLM2 have been reported to have an enhanced ability to mobilize chromosomal genes in Gram-negative bacteria (Marrs, 1981; Holloway, 1969). However, in A. aquaticus, plasmid RP4 was just as effective in mobilizing the Rif ${ }^{R}$ locus as was R68.45. Note that R68.45 was the only one of the three plasmids with which we could transfer both the $\operatorname{Str}^{\mathrm{R}}$ and $\mathrm{Rif}^{\mathrm{R}}$ markers. The frequency of $\mathrm{Rif}^{\mathrm{R}}$ transfer that was found using pBLM2 was not much greater than the frequency of spontaneous mutation in the recipient, but chromosome transfer may have occurred in this experiment, because a low percentage of the recipient cells also acquired the $\cdot \mathrm{Ves}^{+\cdot}$ phenotype (Table 3).

A locus involved in gas vesicle production was linked to the Rif ${ }^{\mathrm{R}}$ locus. Two pieces of evidence suggest that the genes responsible for regulation and production of gas vesicles are not all clustered in one region of the genome. (1) We attempted to complement eight Ves ${ }^{-}$mutants by selecting Rif $^{\mathrm{R}}$ exconjugants after mating to strain $\mathrm{M} 130$, but were only successful with three strains. (2) A putative regulatory locus, which confers constitutive expression of gas vesicles in strain M130 (Konopka, 1977), was not co-transferred to exconjugants in which the $\mathrm{Ves}^{-}$ mutation had been complemented.

These results demonstrate the feasibility of conducting genetic complementation in $A$. aquaticus and of shuttling DNA between $A$. aquaticus and $E$. coli. However, some difficulties remain in using $A$. aquaticus as a genetic system to study gas vesicle production in prokaryotes. This organism has been difficult to mutagenize. Vesmutants occur spontaneously at frequencies up to $10^{-2}$ in batch culture in late stationary phase (A. Konopka, 
unpublished observation). Clones resistant to antibiotics such as Str and Rif are easily isolated. However, we have failed to isolate mutants defective in biosynthetic or catabolic capacity, or resistant to amino acid analogues after treatment with UV irradiation or chemical mutagens such as nitrosoguanidine, acridine orange or ethidium bromide (Bittle, 1986).

\section{References}

BITTLE, C. (1986). Regulation of gas vesicles in prokaryotes. MSc thesis, Purdue University, W. Lafayette, Indiana, USA.

Damerval, T., Castets, A.-M., Gugliemi, G., Houmard, J. \& TANDEAU DE MARSAC, N. (1989). Occurrence and distribution of gas vesicle genes among cyanobacteria. Journal of Bacteriology 171, $1445-1452$.

Gale, E. F., Cundliffe, E., Reynolds, P. E., Richmond, M. H. \& WARING, M. J. (1981). The Molecular Basis of Antibiotic Action, 2nd edn, p. 567. London: Wiley.

Hayes, P. K., Lazarus, C. M., Bees, A., Walker, J. E. \& Walsby, A. E. (1988). The protein encoded by $g v p C$ is a minor component of gas vesicles isolated from the cyanobacteria Anabaena flos-aquae and Microcystis sp. Molecular Microbiology 2, 545-552.

Holloway, B. W. (1969). Plasmids that mobilize the bacterial chromosome. Plasmid 2, 1-19.

Horne, M., Englert, C. \& Pfeifer, F. (1988). Two genes encoding gas vacuole proteins in Halobacterium halobium. Molecular and General Genetics 213, 459-464.

KONOPKA, A. E. (1977). Inhibition of gas vesicle production in Microcyclus aquaticus by L-lysine. Canadian Journal of Microbiology 23, 263-268.

KonopKA, A. E., Moore, R. L. \& STAley, J. T. (1976). Taxonomy of Microcyclus and other nonmotile ring-forming bacteria. International Journal of Systematic Bacteriology 26, 505-510.
LARA, J. C. \& KonOPKA, A. (1987). Isolation of motile variants from gas-vacuolate strains of A. aquaticus. Journal of General Microbiology 133, 1489-1494.

MARRS, B. (1981). Mobilization of the genes for photosynthesis from Rhodopseudomonas capsulata by a promiscuous plasmid. Journal of Bacteriology 146, 1003-1012.

Miller, J. H. (1972). Experiments in Molecular Genetics, pp. 431-433. Cold Spring Harbor, New York: Cold Spring Harbor Laboratory.

RAJ, H. D. (1983). Proposal of Ancylobacter gen. nov. as a substitute for the bacterial genus Microcyclus Ørskov 1928. International Journal of Systematic Bacteriology 33, 397-398.

Staley, J. T. (1968). Prosthecomicrobium and Ancalomicrobium: new prosthecate freshwater bacteria. Journal of Bacteriology 95, 19211942.

Tandeau de Marsac, N., Mazel, D., Bryant, D. A. \& Houmard, J. (1985). Molecular cloning and nucleotide sequence of a developmentally regulated gene from the cyanobacterium Calothrix PCC 7601 : a gas vesicle protein gene. Nucleic Acids Research 13, 7223-7236.

Thomas, C. M. \& SMITH, C. A. (1987). Incompatibility group P plasmids: genetics, evolution, and use in genetic manipulation. Annual Review of Microbiology 41, 77-101.

VAN ERT, M. \& Staley, J. T. (1971). Gas-vacuolated strains of Microcyclus aquaticus. Journal of Bacteriology 108, 236-240.

WaLSBY, A. E. (1971). The pressure relationships of gas vacuoles. Proceedings of the Royal Society B178, 301-326.

WalsBY, A. E. (1978). The gas vesicles of aquatic prokaryotes. Symposia of the Society for General Microbiology 28, 327-358.

W ALSBY, A. E. (1981a). Cyanobacteria: planktonic gas-vacuolate forms. In The Prokaryotes, pp. 224-235. Edited by M. P. Starr, H. Stolp, H. G. Trüper, A. Balows \& H. G. Schlegel. New York: Springer-Verlag.

WALSBY, A. E. $(1981 b)$. Gas-vacuolate bacteria (apart from cyanobacteria). In The Prokaryotes, pp. 441-447. Edited by M. P. Starr, H. Stolp, H. G. Trüper, A. Balows \& H. G. Schlegel. New York: Springer-Verlag.

ZiNDER, S. H., ANGuish, T. \& Lobo, A. L. (1987). Isolation and characterization of a thermophilic acetotrophic strain of Methanothrix. Archives of Microbiology 146, 315-322. 